\title{
Opportunities, Challenges and Strategies for the Internationalization Development of Higher Vocational Education in the New Situation
}

\author{
Dan Wang \\ Shanghai Publishing and Printing College, Shanghai, China \\ Email: 563169421@.q.com
}

How to cite this paper: Wang, D. (2019). Opportunities, Challenges and Strategies for the Internationalization development of Higher Vocational Education in the New Situation. Creative Education, 10, 2174-2185. https://doi.org/10.4236/ce.2019.1010157

Received: September 30, 2019

Accepted: October 12, 2019

Published: October 15, 2019

Copyright () 2019 by author(s) and Scientific Research Publishing Inc. This work is licensed under the Creative Commons Attribution International License (CC BY 4.0).

http://creativecommons.org/licenses/by/4.0/ (c) (7)

Open Access

\begin{abstract}
The opening-up of national education has come into a new period of development, the internationalization of higher vocational and technical education should conform to the overall situation of service, for our own use, raise the level and intention of the development trend, and at the same time, should cooperate with the "One Belt One Road" construction, to help China's education quality capacity to go out. The internationalization development level of higher vocational and technical colleges in China has the characteristics of the coexistence of strategic development and imbalance, the coexistence of advantages and disadvantages, opportunities and challenges, from strategic planning and system construction, self-support and the pursuit of resources, docking strategy and characteristic development, intelligence introduction and resource output synchronization; operating schools openly and party building promote each other to discuss the effective path of developing education internationalization in higher vocational and technical colleges under the new background.
\end{abstract}

\section{Keywords}

Higher Vocational and Technical College, Internationalization, Education Open-Up, One Belt One Road

\section{The Meaning and Significance of the Internationalization of Higher Vocational and Technical Education}

\subsection{The Meaning of the Internationalization of Higher Vocational and Technical Education}

The definition of internationalization of higher education in Chinese academic 
circles has not formed a unified opinion, but there are two views being widely accepted. One is the definition of internationalization of higher education by the International Association of Universities (IAU), an official partner of UNESCO, that is, "internationalization of higher education is a process of combining cross-cultural views and atmosphere with university teaching and scientific research work, which is a change of schools from inside to outside, from bottom to top, and from top to bottom." The other definition of the internationalization of higher education is by the Canadian scholar Jane Knight, that is, "integrating the international, cross-cultural and global dimensions into the purpose, function or transmission process of higher education" (Knight, 2011). The common feature of the two mainstream definitions is that the internationalization of higher education is emphasized as a process. The process nature of internationalization of higher education determines that the internationalization of higher education is a systematic project composed of profound intension and rich extension. Specifically, the internationalization of higher education should be the effective connection, integration, inoculation and selective adoption between international educational resources. Through these processes, the purpose of enhancing the effect of education can be achieved, and the mission of higher education should be better fulfilled.

Due to the differences between the operational background, the form of school operation, the goal of student training and the evaluation system of higher vocational and technical colleges and universities, the extension of internationalization of higher vocational and technical colleges and universities should be different from that of the internationalization of university education. The extension of internationalization of higher vocational and technical education consists of the internationalized way of thinking at work, the content of work and the form of work. Combining the opinions of the academic circles, the specific representations are as follows: internationalized school operational concept and planning, internationalized work coordination mechanism, internationalized curriculum and practical training, internationalized composition of students and teachers, internationalized school operation form, internationalized diplomas and certificates, internationalized employment orientation.

\subsection{Significance of Internationalization of Higher Vocational and Technical Education}

The internationalization of higher vocational and technical education is the inevitable result of economic globalization and regional economic integration. It is the only way for China's higher vocational and technical education to achieve sustainable development. It is also the essential approach to advance internal fulfillment and to realize characteristic development in higher vocational and technical colleges. The cultivation of professional human resource with practical techniques and skills is the goal as well as the specialty of operating a higher vocational and technical college. The goal of internationalization of higher vocational and technical education is through international development and inter- 
national activities to enable higher vocational and technical colleges to cultivate professional human resource with a broad international vision and flexible innovative thinking, a comprehensive career alteration capability desired by everywhere, and international competitiveness that take up an occupation in different economic and cultural contexts. At the same time, the techniques and skills acquired by students should also be in line with international standards and have international versatility. Through the training of such human resource, we can achieve the goal of advance higher vocational and technical education to serve social and economic development in a better way, and to promote the development of economic globalization and regional economic integration through the internationalization of human resource.

\section{An analysis of the Current Situation of Internationalization of Higher Vocational Education in China}

In the following section, what has been analyzed is the status quo and characteristics of the internationalization of China's higher vocational and technical education. Meanwhile, the development status and existing problems of the internationalization of higher vocational and technical colleges are unfolded, so as to build a theoretical foundation for higher vocational and technical colleges to carry out internationalization activities and promote the internationalization process in a more effective way.

\subsection{The Coexistence of Strategic Development and Unbalanced Development}

With economic globalization and regional economic integration and the demand of the colleges and universities to advance internal fulfilment and to realize characteristic development, all higher vocational and technical colleges, especially the national main force higher vocational and technical colleges and representative higher vocational and technical colleges, have attached a high value to internationalization of education as a development strategy of the school, that the colleges and universities are devising and carrying out internationalization operation consciously, strategically and in a planned way. "More and more higher vocational and technical colleges have placed emphasis to international exchange and cooperation work from simple foreign affairs to a strategic level, and such operations have become an important part of the overall development planning of the school." (Mai, 2016) "Internationalization at the 'principle level' has been paid more and more attention in the national representative higher vocational and technical colleges." (Mo, 2017) When internationalization is being value data strategic height by higher vocational and technical colleges, of which the degree of internationalization is getting higher and higher, while the form of cooperation is becoming more and more diversified, and the depth of cooperation is getting more exhaustive than ever. The internationalization activities of higher vocational and technical colleges have developed from simple for- 
eign affairs reception and cooperation memorandums to more and more substantive cooperative interactions with developed countries and operating in coordination with national development strategies to cooperatively interact with colleges and universities in the "Belt and Road Initiative" route penetrated regions. They have developed from the once invariable "bringing in and going out" (introducing foreign educational resources and sending teachers and students to study abroad) to explore exporting their own advantages in educational resources (technology, standards, student training model), to strength overseas school operation and foreign student training. Taking the most normative and representative form of international cooperation, the Sino-foreign cooperative school operation, as an example, according to the data of the information platform for the supervision of Sino-foreign cooperative schools of the Ministry of Education of the people's Republic of China, as of June 2018, a total of 2576 Chinese-foreign cooperative school operation institutions and projects have been established or conducted nationwide with the approval of the examining and approving authorities, among which, there are 800 Sino-foreign cooperative operation projects and institutions in higher vocational and technical education, accounting for $31 \%$ of the total number of Sino-foreign cooperative operation projects and institutions in higher vocational and technical colleges and universities. "according to statistics, in 2016, 100 higher vocational and technical colleges in China have developed 283 abroad (overseas) recognized profession or subject teaching standards." (Shanghai Academy of Educational Sciences, 2017) Many higher vocational and technical colleges, especially those with obvious geographical advantages, such as those in the southeast coast areas and those adjacent to the ASEAN borders, have tried and successfully carried out the training of foreign students and operating schools abroad.

Due to the limitation factors of the positioning and qualification of school operation, quality of student, social concept etc., the international development of higher vocational and technical colleges not only tends to open up the level gap with the international development of undergraduate universities, but also the degree of international development between different higher vocational and technical colleges is also uneven. In recent years, the internationalization of higher vocational and technical colleges has developed in a rapid pace, however, the degree of internationalization has shown an unbalanced state, which is characterized by the rapid development of the internationalization of the coastal higher vocational and technical colleges and the slow development of the internationalization of the central and western higher vocational and technical colleges, and the strong momentum of development in the main force higher vocational and technical colleges while the deficient motivation of development in the ordinary higher vocational and technical colleges. Again, taking Sino-foreign cooperative school operation as the example, providences located along the southeast coast, and those with a higher degree of opening up to the outside world is relatively have a large number of cooperative operational schools in vocational and technical education, of which the scale is relatively large, the effect 
is also more obvious, such as Jiangsu, Zhejiang, Shanghai, Guangdong provinces, the four provinces accounted for nearly $50 \%$ of Sino-foreign cooperative school operation in China in the area of higher vocational and technical education; while the provinces located in the central and western regions, such as the five provinces of Tibet, Qinghai, Xinjiang, Gansu and Ningxia have not yet a program or institution of Sino-foreign cooperative higher vocational and technical education in operation. These institutions are restricted by geography, awareness, policy, capital, cooperative resources, etc., that the introduction of foreign cooperative resources is greatly restricted, consequently the degree of internationalization development is low. Meanwhile, for the representative higher vocational and technical colleges and main force higher vocational and technical colleges have enjoyed the support in multiple aspects of funds, policies and so on, and after a certain cycle of development, the internationalization of these institutions is generally faster in speed and higher in degree than the internationalization of ordinary vocational colleges and universities. On the other hand, the international development of higher vocational and technical colleges, especially the national main force higher vocational and technical colleges, has indeed made vigorous development in recent years, however, it shows the negative characteristics of more resources introduced with few resources exported, more short-term exchanges with less academic education, strong in the desire for internationalization not clear in the management and so on. These cases are the embodiment of insufficient and unbalanced development in the internationalization of higher vocational and technical education.

\subsection{The Coexistence of Advantages and Disadvantages While Facing Challenges in the Opportunities}

The core and feature of operating higher vocational and technical education is the application of technical skills training. The cultivation of practical technical skills is not only the mission of higher vocational and technical colleges, but also their core competitiveness. In the course of school operation for several decades, China has formed a group of higher vocational and technical colleges with obvious characteristics of school operation. For example, Shanghai publishing and printing college, has cultivated more than 50,000 highly skilled talents for China's publishing and printing industry after decades of schooling, and their students have won silver and bronze awards in the world skills competition. The major professions of these institutions have accumulated experience and developed in a rational way, formed characteristic profession groups with advantages and competitiveness in the skill oriented industries and even leading the development of certain industries. The professional and technical advantages of higher vocational and technical colleges have become the capital of its school development. In addition, the higher vocational and technical colleges take the "combination of production and education" as the key of school operation, and take servicing the industries as their own responsibility, and students' education is more in line with employment requirements, that their "services" can be easily 
transformed into social productive capacity, with more obvious output effect is, and can help to form social influence. In today's economic globalization and regional economic integration, economic cooperation and frequent trades will inevitably promote the spontaneous flow of educational elements and the spontaneous optimization of educational resources, promoting the active development of activities such as "introduction" and "exporting" in higher vocational and technical colleges, so that the internationalization of higher vocational and technical colleges has certain advantages. Especially in the context of the "One Belt, One Road" proposal, China's opening up to the outside world will advance to a new stage. The opening to the outside world of higher vocational and technical education will also enter a new phase with broader opportunities. The needs of industries for the technical and skilled human resource will also become more and more prosperous. The cooperation and exchanges between higher vocational and technical colleges and universities along the "Belt and Road Initiative" route will also become closer and in-depth, and the corresponding policy support will be more and more in place.

At the meantime, the international development of higher vocational and technical colleges also has obvious disadvantages and faces certain challenges. Although the internationalization level of higher vocational and technical colleges has been improved to a certain extent in recent years, due to the limitation of school operation, the financial ability, the basis of students, the level of teachers, and its overall strength to attract international cooperative partners are weaker than those of undergraduate colleges and universities, which leads to a lot of difficulties to its internationalization development. Development of school operation of most of the higher vocational and technical colleges relies on local financial support, and their ability to obtaining resources and conditions such as external funds and policies is also relatively weak, so the financial foundation is limited, and the limited financial foundation will inevitably lead to the limited space and capacity of its international cooperation. Enrolling of higher vocational and technical colleges is the third batch of enrolling by college entrance examination, that the low level of school operation leads to a low attractive power, which naturally isolated a group of excellent students outside the door, so that the overall level of student quality is not high, students' general knowledge foundation, foreign language level, learning enthusiasm and learning ability are not ideal, which will reduce the implementation effect of internationalization project in higher vocational and technical colleges. The faculty qualification level of higher vocational and technical colleges, especially the international vision and international ability of teachers, is generally weaker than that of undergraduate colleges. Higher vocational and technical colleges are less capable to implement specific international cooperation projects, and sometimes there is the embarrassment of "no competent personnel available". The level of school operation and the financial ability of higher vocational and technical colleges are not sufficient, and the popularity and social reputation of most colleges are not prestigious, which leads to their insufficient attraction to international cooperative 
partners and high-level international teachers. Still taking Sino-foreign cooperation in school operation as the example, higher vocational and technical colleges are restricted by the bottleneck of the level of school operation and the overall level of students, that the conflict between the goal of interests in the foreign side and the orientation of public welfare principle of Sino-foreign cooperative operating schools in China, which makes contradictions between Chinese and foreign sides in establishing cooperation foundation and mutual trusted understanding become prominent, and finding the well matched foreign cooperative partner of has become the primary challenge for higher vocational and technical colleges to carry out cooperative school operation. It is difficult to attract and drive overseas colleges to cooperate with higher vocational and technical colleges. It is precisely based on this contradiction, the cooperation resources introduced by higher vocational and technical colleges are also uneven in the quality. The weakness of the overall strength of higher vocational and technical colleges leads to their weak ability to adapt to the development of internationalization, and their international development is facing pressure and challenges.

\section{Study on the Route of International Development of Higher Vocational and Technical Colleges}

\subsection{Promote Strategic Planning and Institutional Construction Simultaneously}

The premise of the internationalization of higher vocational and technical colleges is the internationalization of the concept for operating a school. Without an internationalized concept of school operation, the internationalization course of higher vocational and technical education would become a "water without a source, or a tree without roots." While the most direct and effective carrier for a school to transform the concept of internationalization into the achievement of internationalization is its strategic development plan of internationalization. If a college has no target orientation and systematic planning for the development of internationalization course, it is difficult to implement feasible and effective international actions. The "internationalization" of a school will become a mere formality or meaningless slogan. Many famous universities in the world have achieved the development of schools through the development of internationalized planning strategies such as forward-looking, feasible international development goals and a series of internationalized actions. Internationalization is an intrinsic requirement for higher vocational and technical colleges to advance internal fulfillment, and also a response to the need of adapting to the competition situation of "economic globalization" and "regional economic integration" to cultivate the human resource, especially in the background of "Belt and Road Initiative" and under the favorable development opportunities of the regional foreign-oriented economy, higher vocational and technical colleges should attach importance to internationalization to be the major development strategy plan of the school. Also, international development should be incorporated into a 
school's medium and long-term development plan, into the "13th Five-Year Plan" and the future "14th Five-Year Plan", as well the legalization process of university system reform.

Overall planning is the premise, while system development is the guarantee, and improving the mechanism is the mainline. In planning and developing their own internationalization, higher vocational and technical colleges should also pay attention to combine the development of school's own legal system, namely to establish and improve internationalization development related regulation system under the framework of superior laws corresponding laws and regulations, to ensure that all operations are abided by laws from personnel and agency deployment to the management process and to the specific project operation, so that colleges can rigorously carry out activities and projects of internationalization. A good set of laws and regulations can guide and escort the internationalization development of higher vocational and technical colleges and promote the effect of internationalization development of colleges and universities. At the same time, it is necessary to establish and improve a scientific, standardized and effective internal management mechanism. The internationalization of an institution by relying solely on the department of foreign affairs (international cooperation and exchange) cannot necessarily achieve high level and high efficiency. The goal of internationalization is to cultivate international human resource, and the cultivation of human resource mainly depends on professional teaching. Only by giving full play to the subjective initiative of each teaching implementation unit in the school, as well as the simultaneous participation and coordinated development of teaching management departments, can the effect of "get twice the result with half the effort" be achieved. It is a systematic project for the school to realize international development, that it is very important to establish an effective internal management mechanism. In the process of the internationalization of a school, how to define the functions between specialized institutions and teaching units, motivate the faculty to participate in the internationalization construction, and create a good international working atmosphere has become an important subject.

\subsection{Self-Reliance Should Go Hand in Hand with Striving for Resources}

In addition to positive actions and innovation in an enterprising way to develop internationalization, higher vocational and technical colleges also have to strive for external resources. In terms of striving for external resources, in addition to actively striving for favorable policies and financial resources of the state and local governments, the more important thing is to strive for resources of enterprises and industries. Academic-industry partnerships and college-enterprise alliance are lifelines and accelerators for the survival and development of higher vocational and technical colleges. The development of higher vocational and technical colleges depends on enterprises and industries, on the other hand, they 
also facilitate the development of enterprises and industries. Effective college-enterprise cooperation can not only improve the quality of human resource training, but also strengthen the close and in-depth cooperation between colleges and enterprises. Higher vocational and technical colleges should make full use of the platforms such as college-enterprise cooperation, actively strive for, unite industry and enterprise resources to participate in school operation, supplement school operation funds, and improve the level of school operation. At the same time, taking advantage of the convenient conditions of school-enterprise cooperation, we should introduce internationally prestigious scholars and technological experts from the industry to participate in the formulation of school human resource training programs and educational practice; also, we should introduce international standards of industry and technology and international equipment into the teaching and learning process, so as to achieve seamless connection between education and the internationally commonly used skill standards; and to create conditions for students while encouraging and guiding students and teachers to practice and study in well-known multinational enterprises in each industry, to participate in college-enterprise cooperation projects and international cooperation projects, so as to stimulate their potential, and to truly cultivate human resource with international vision, knowledge of international rules and mastery of international skills.

\subsection{The Integration of Strategies and Characteristic Development}

The ultimate goal of operating a higher vocational and technical college is to train useful skilled human resource for the socialist undertaking. Therefore, higher vocational and technical colleges should pay close attention to the national political direction and diplomatic policy when developing their own internationalization, and at the same time follow the footsteps of the times and keep in line with the major national strategies. Under the current situations, we should accurately match the specific directional contents of The National Higher Vocational Education Development Plan, the Modern Vocational Education system Construction Plan (2014-2020), the Action Plan for the Innovation and Development of Higher Vocational Education (2015-2018), as well as the major development plans in service of the country such as "Belt and Road Initiative". At present, many higher vocational and technical colleges, especially those with regional borders and those with geographical characteristics, have actively carried out a large number of feasible and effective educational cooperation programs with colleges and universities in the countries of the "Belt and Road Initiative" route penetrated regions, which have not only contributed to the major strategies of serving the country, but also enhanced their own level of internationalization.

"It is impossible to produce a satisfactory result for colleges to integration with international standards' or 'training internationalized human resource' in a indiscriminate, unconstrained and bold manner." (Li \& Liu, 2016) During the process of achieving international development and keeping in line with nation- 
al strategies, on the other hand, higher vocational and technical colleges should also follow the three principles of development, namely practical, scientific and characteristic. In this regard, firstly, it is necessary to develop by grasping the key points and conduct with focus, and to plan international development activities around school operational attributes and characteristics in the aspect of techniques and skills as well as practice and training. The second is to carry out the implementation of international cooperation projects in a steady and feasible manner according to the basis of their own education and actual conditions. At the same time, they should pay attention to cooperation with overseas high-quality vocational education resources, and to effectively advance their internal fulfilment and quality of student training through international cooperation and exchanges. Therefore, in formulating and implementing the international development goals, the institutions cannot "go after something like a flock of ducks", nor can they "get it all at once". Based on their own advantages and disadvantages, they should reflect themselves on their own expertise and characteristics, adapt to local conditions, give full play to their characteristics, and take the initiative to adapt to the changes, find the opportunity of internationalization and a practical and feasible international development path. Institutions should act according to actual circumstances, considering the multiple factors of the basis of operating a school, school goals, development stage, composition of professions, characteristic advantages, conditions of students, resource status, etc., to scientifically and rationally plan their own international development goals and paths. Taking the example of in responding to our country's "Belt and Road Initiative", the higher vocational and technical colleges should focus on the local "Belt and Road Initiative" project development plans to develop related professions, jointly cultivate the human resource needed by the industries, and to fulfil the requirements of the project plans for internationalized professional human resource, so as to improve the level of employment and entrepreneurship of students.

\subsection{Synchronizing Intelligence Introducing and Resource Export}

The internationalized school operation of higher vocational and technical colleges is mainly carried out by "introducing" and "exporting". Practice shows that through the implementation of "introduction", higher vocational and technical colleges really promote the cultivation of their own students and faculty, as well as the improvement of education and training abilities. "Introducing" is a long-term scheme and a systematic project. Higher vocational and technical colleges can continuously introduce various forms of overseas high-quality educational resources based on their own needs. The contents of introduction can be visible people, money and materials or invisible educational ideas and intellectual property rights, as well as the introduction of the traditional forms such as teachers, books and curricula, or the introduction of vocational qualification systems, professional standards and teaching standards, and the introduction of human resource cultivation mode etc., of which the ultimate purpose is to realize 
the matching of college operation and international skills standards, and the educational results are in line with industrial requirement standards for international human resource under the background of economic integration. On the other hand, "exporting" is mainly reflected in the fact that teachers and students go abroad for further study, field study and exchange, as well as a small amount of employment. However, this kind of "exporting" is a lower level of "output", its essence is another form of "introduction", that is, the introduction of overseas intellectual resources through teachers and students to study, exchange and "learn from" abroad. Higher vocational and technical colleges could further expand the form of "exporting", such as participating in skill competitions abroad, to promote teaching and learning through competition, and by establishing cooperation with multinational companies to provide internships and employment opportunities for students. Under the new situation of education opening to the outside world, China's higher education has changed from "studying abroad" and "job hunting abroad" to "studying in China" and "operating schools abroad". Higher vocational and technical colleges should also adapt to the situation, take the initiative, try boldly and confidently to deepen the intension of "exporting" while "introducing" and achieve a high level of "exporting". We can make more efforts in the training of foreign students, the of technical assistance training to foreign countries and to operate schools abroad when conditions are available, as undergraduate colleges and universities is doing, so as to realize the integration of "resource export" and the introduction of intelligence. Higher vocational and technical colleges also have the responsibility and obligation to contribute to the realization of the "exporting" of national education resource and serving the country's "Belt and Road Initiative" strategy. In Some Opinions on the Opening-up of Education in the New Period, it has been deployed to encourage universities and vocational colleges to cooperate with enterprises to realize internationalization. In fact, the demand for vocational and technical skills training and education is very strong for the youth of some countries in the "Belt and Road Initiative" route penetrated regions. In this regard, on the one hand, higher vocational and technical colleges should accumulate strength, reform ideas and take the initiative to service. At the same time, the national level should pay enough attention to the "exporting" of higher vocational and technical education and the cultivation of foreign students, provide necessary guidance and policy support.

\subsection{Mutual Promotion of Opening up of Education and Development of the Party}

The internationalization activity of higher vocational and technical colleges is the performance of opening up of education, and is the integration and cooperation of educational resources under different cultural backgrounds. This activity necessarily involves the policy guidelines of economic, political, cultural, foreign affairs of different countries and regions, and even other many factors such as ideology. The goal of internationalization determines the nature of its work is 
concerning foreign affairs or foreign nations, and nothing is minor matter regarding foreign affairs. When conducting international cooperation and exchanges, institutions should grasp the principle of "not stepping on the red line and keeping the bottom line", firmly establish the awareness of party development, and strengthen the adherence to the party's leadership, carry out party development work without compromise, in order to adhere to the correct direction of socialist educational operation, and to escort the internationalized education of higher vocational and technical colleges, so as to realize the mission of the higher vocational and technical colleges to cultivate socialist builders and successors with Chinese characteristics.

At present, many high vocational schools have started the process of internationalization, but due to the constraints and immature factors, there are various problems. However, vocational colleges are in a stage of development, and the national education policy is bringing opportunities to vocational education. If we seize the opportunity to expand and deepen the internationalization of higher vocational education, promote its comprehensive development and improvement, and make it internationally competitive, it will be a great opportunity for the development of higher vocational education in China.

\section{Conflicts of Interest}

The author declares no conflicts of interest regarding the publication of this paper.

\section{References}

Knight, J. (2011). Higher Education in Turmoil-The Changing World of Internationalization (pp. 25-26, 53). D. F. Liu (Trans.). Beijing: Peking University Press.

Li, Q. C. \& Liu, Y. (2016). Exploring the Internationalization Concept and Path of Characteristic Local Universities under the "Belt and Road Initiative". Chongqing Higher Education Research, 4, 26-31.

Mai, L. Y. (2016). Discussion on the Characteristics of International Management and the Construction of Mechanisms in Higher Vocational and Technical Colleges. 19-23. EXploration of Higher Vocational Education, December, 15,

Mo, Y. W. (2017). Internationalization of Higher Vocational Education: Intension, Practice and Reform Trend: Based on the Investigation and Analysis of 100 National Higher Vocational Representative Institutions. Vocational and Technical Education, 38, 24-28.

Shanghai Academy of Educational Sciences, Max Institute (2017). 2017 Annual Report on the Quality of Higher Vocational and Technical Education in China (p. 45). Beijing: Beijing Higher Education Press. 